Article

\title{
Synthesis and Electrochemical Proprieties of Novel Unsymmetrical Bis-Tetrathiafulvalenes and Electrical Conductivity of Their Charge Transfer Complexes with Tetracyanoquinodimethane (TCNQ)
}

Tahar Abbaz ${ }^{1, *}$, Amel Bendjeddou ${ }^{2}$, Abdelkrim Gouasmia ${ }^{1}$, Zine Regainia $^{2}$ and Didier Villemin ${ }^{3}$

1 Laboratory of Organic Materials and Heterochemistry, University of Tebessa, Constantine Road, Tebessa, 12000, Algeria; E-Mail: akgouasmia@hotmail.com

2 Laboratory of Applied Organic Chemistry, Heterocyclic Chemistry Group, Department of Chemistry, Faculty of Science, University of Annaba, Annaba, 23000, Algeria;

E-Mails: bendjeddouamel@gmail.com (A.B.); regainiadz@yahoo.fr (Z.R.)

3 Laboratory of Molecular and Thio-Organic Chemistry, UMR CNRS 6507, INC3M, FR 3038, Labex EMC3, ENSICAEN \& University of Caen, 14050 Caen, France; E-Mail: didier.villemin@ensicaen.fr

* Author to whom correspondence should be addressed; E-Mail: abbaz_tahar@yahoo.fr; Tel.: +213-7-9227-2719; Fax: +213-3095-2935.

Received: 18 May 2012; in revised form: 13 June 2012 / Accepted: 14 June 2012 /

Published: 25 June 2012

\begin{abstract}
The synthesis and properties of a series of bis-tetrathiafulvalenes (bis-TTFs) containing nitrophenyl, aminophenyl or dimethylaminophenyl is reported. The synthesis was carried out by using routes involving Wittig-type, cross-coupling, reduction and alkylation reactions. The electron donor ability of these new compounds has been measured by cyclic voltammetry (CV). Charge transfer complexes with tetracyanoquinodimethane (TCNQ) were prepared by chemical redox reactions. The complexes have been proven to give conducting materials.
\end{abstract}

Keywords: tetrathiafulvalenes; redox potentials; organic materials; conductivity 


\section{Introduction}

Tetrathiafulvalene (TTF) and its derivatives have attracted attention for many years because of their electron donor ability and the electrical conductivity of their charge transfer salts, which was started in 1973 with the synthesis of the tetrathiafulvalene-tetracyanoquinodimethane complex (TTF-TCNQ) by Cowan and coworkers [1]. Since then, the progress made in the synthesis of such molecules has been closely related to the discovery of new materials [2] exhibiting conducting [3-6], superconducting [7,8], magnetic [9-11], or optical properties [12,13].

The TTF core and its derivatives - due to their characteristics, in particular their stability and reversible redox character-have found a significant number of applications in materials chemistry [14] such as molecular switches rotaxanes and catenanes [15], conductive materials [16] and superconductors [17], complex with the $C_{60}$ [18], conductive polymers [19], materials for nonlinear optics [13], sponges cations [20], ferromagnetic organic magnets [9], liquid crystals [21], and dendrimers [22]. Our research is focused on the conducting and superconducting materials in the hope to improve results in the field and to aim to find an organic superconductor at room temperature.

Dimeric tetrathiafulvalenes are currently of interest to chemists for their applications in organic molecular materials. They can be divides into two types: one is linked through conjugated $\pi$-systems and the other through non-conjugated $\sigma$-chains [2].

In a continuation of previous work of our group [23-25], in this paper we now describe the synthesis and properties of some new unsymmetrically $\pi$-donors of bis-TTFs which linked directly by $\sigma$-bond with alkyl chains of different lengths, containing nitrophenyl, aminophenyl or dimethylaminophenyl groups, synthesized via cross-coupling, reduction and alkylation methods. The redox behavior of such precursors has been studied by cyclic voltammetry and finally the electrical conductivity of charge transfer complexes was measured.

\section{Results and Discussion}

Several steps are needed to convert the 4-(p-nitrophenyl)-1,3-dithiole-2-thione $\mathbf{1 a}$ in the corresponding 4-(p-nitrophenyl)-1,3-dithiolium tetrafluoroborate 4 (Scheme 1).

Scheme 1. Synthetic route for the preparation of 4-( $p$-nitrophenyl)-1,3-dithiolium salt 4.

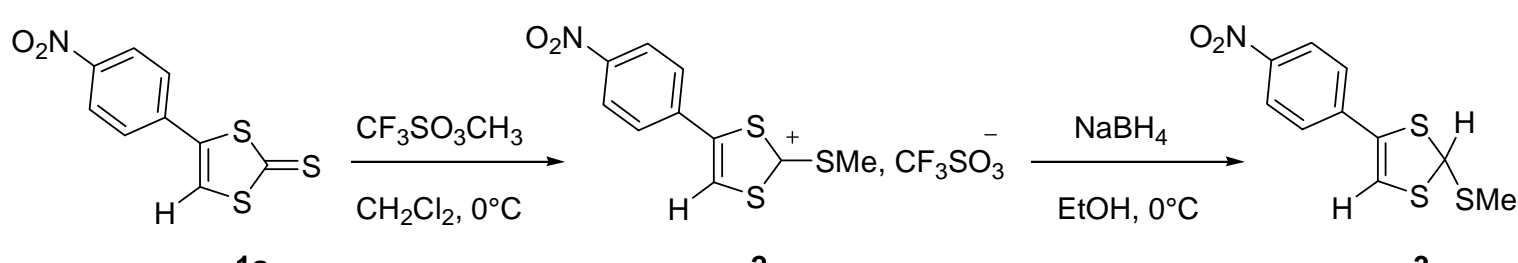

1a

2

3

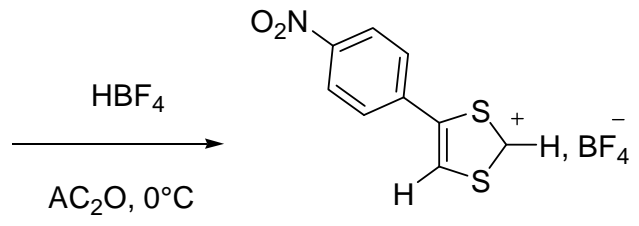

4 
The first step consists in methylating the thione 1a [26] with methyl triflate in anhydrous $\mathrm{CH}_{2} \mathrm{Cl}_{2}$ at $0{ }^{\circ} \mathrm{C}$. The desired salt, 2-methylthio-4-( $p$-nitrophenyl)-1,3-dithiolium trifluoromethane sulfonate 2 , isolated as a precipitate by simple addition of cold ether in $95 \%$ yield. During the second step, the salt 2 placed in suspension in ethanol is reduced by sodium borohydride at $0{ }^{\circ} \mathrm{C}$. 2-methylthio-4-( $p$-nitrophenyl)-1,3-dithiole 3 is isolated as oil in 75\% yield, which is treated directly in the next step. Finally, dethiomethylation of the reduced product 3 with tetrafluoroboric acid in acetic anhydride at $0{ }^{\circ} \mathrm{C}$ leads to 1,3 -dithiolium 4 expected with a yield of $45 \%$.

The synthesis of electron donors $9, \mathbf{1 0 a}$ and $\mathbf{1 0 b}$ based on a multi-step procedure were carried out as shown in Scheme 2.

Scheme 2. Synthetic route of mono-tetrathiafulvalenes (TTFs) 9 and $\mathbf{1 0 .}$

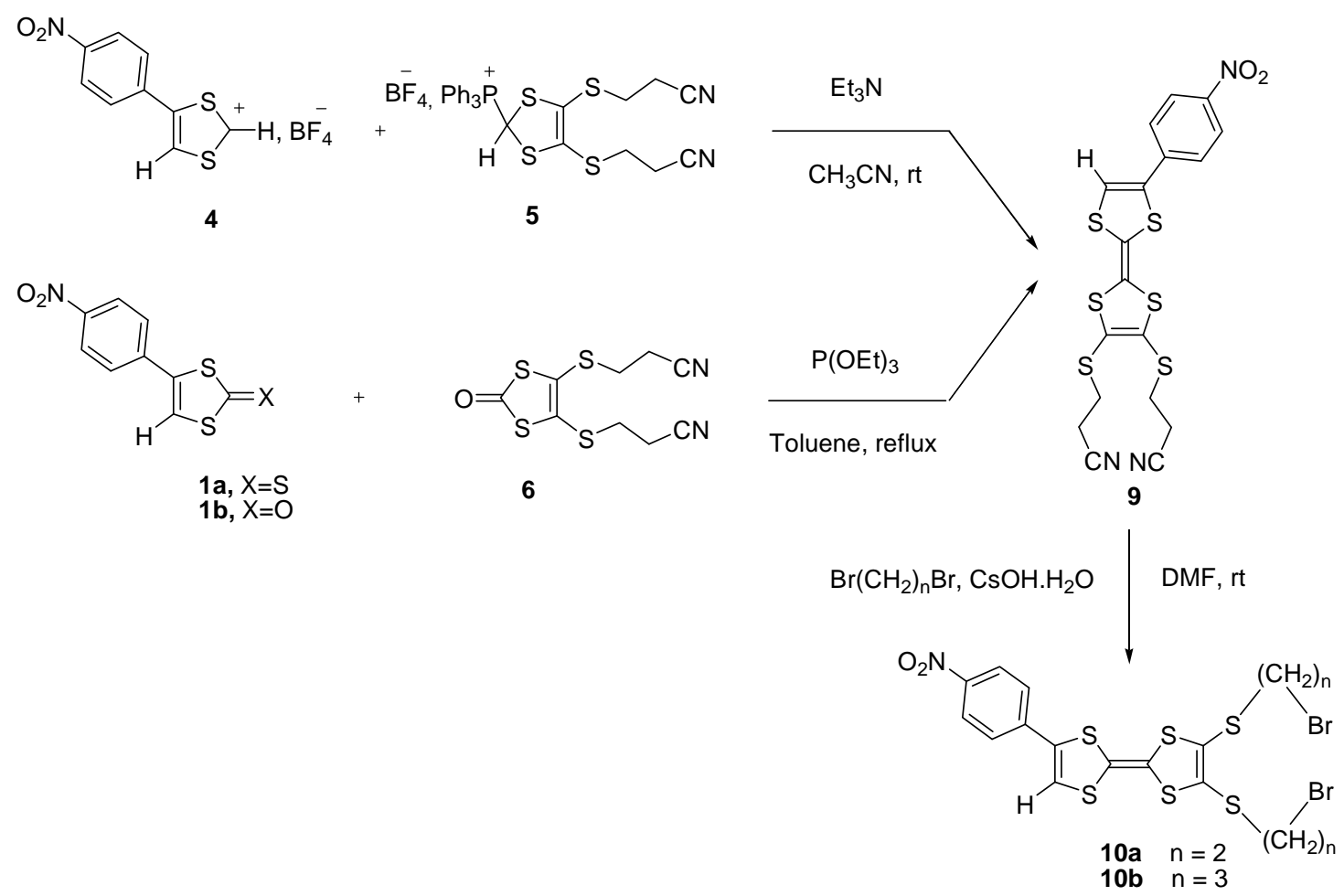

We have synthesized 2,3-bis(2-cyanoethylthio)-6- $p$-nitrophenyl tetrathiafulvalene 9 by two different methodologies. The first involved a Wittig-type reaction using a weak base such as triethylamine which does not remove cyanoethyl protecting groups. The action of triethylamine in acetonitrile at room temperature on the phosphonium salt 4-( $p$-nitrophenyl)-1,3-dithiole-2-yl-triphenylphosphonium tetrafluoroborate 5 [27], generates the ylid, which reacts on the 1,3-dithiolium salt 4 to give the adduct intermediate. This is converted, by elimination of triphenylphosphine to 2,3-bis(2-cyanoethylthio)-6- $p$-nitrophenyl tetrathiafulvalene 9 in 30\% yield.

The second route involved the reaction of chalcogenones 4-( $p$-nitrophenyl)-1,3-dithiole-2-thione 1a or 4-( $p$-nitrophenyl)-1,3-dithiole-2-one 1b [28] with 5-bis-(2-cyanoethylthio)-1,3-dithiole-2-one 6 [27], via a cross coupling method [29] in toluene at reflux in the presence of triethyl phosphite. As the reactivity of precursor 2-one was much higher than that of precursor 2-thione, mono-TTF 9 bearing two cyanoethylthio groups was obtained in $35 \%$ and $57 \%$ yield, respectively. 
Scheme 3. Synthetic route of bis-TTFs 11-14.

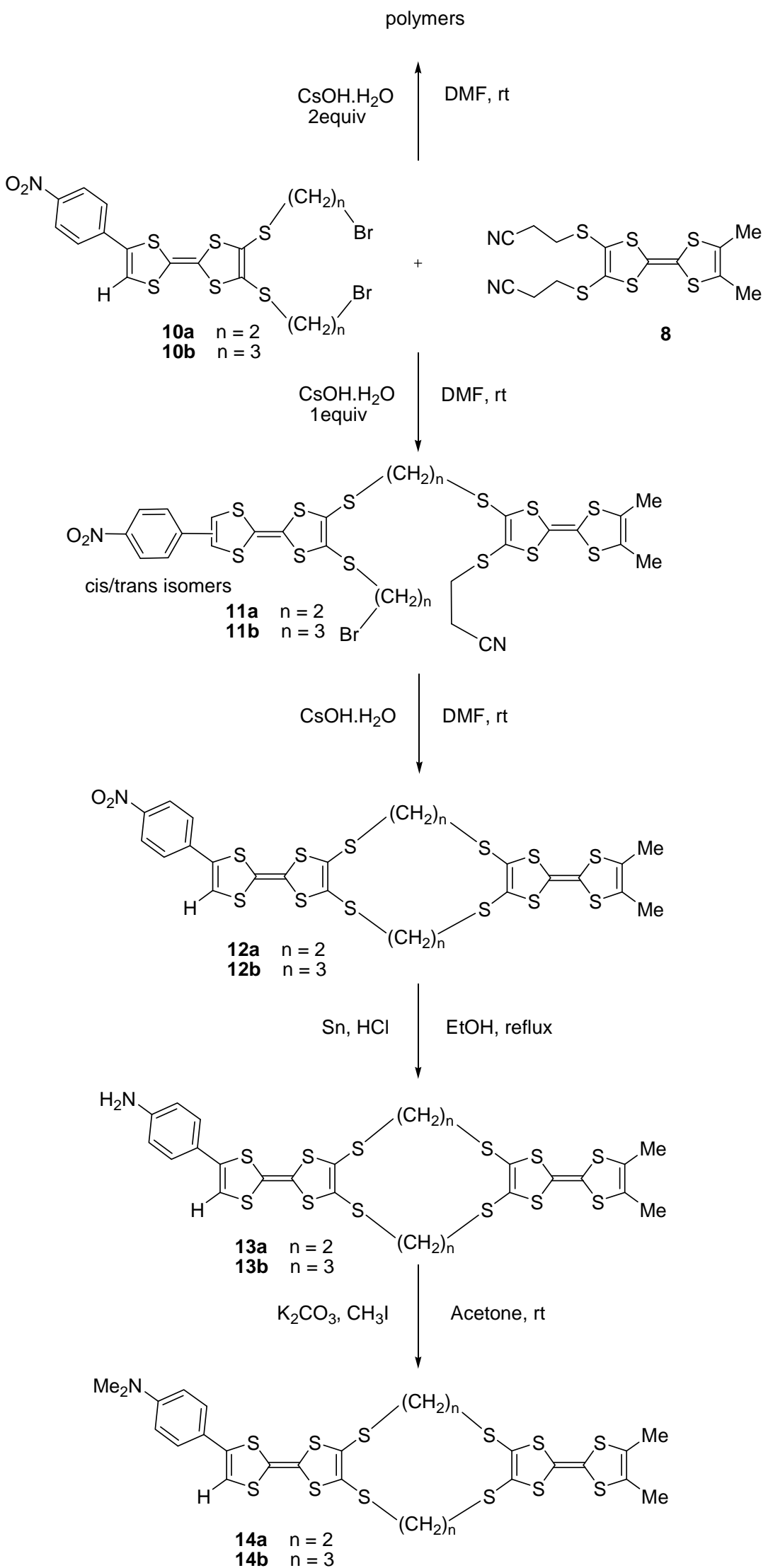

The deprotection of bis(2-cyanoethyl) groups of 9 with the aid of $\mathrm{CsOH}$ and sequentially reaction with 10 equivalents of 1,2-dibromoethane or 1,3-dibromopropane afforded the unsymmetrically 
functionalized mono-TTF derivatives 2,3-bis(2-bromoethylthio)-6- $p$-nitrophenyl tetrathiafulvalene 10a or 2,3-bis(3-bromopropylthio)-6-p-nitrophenyl tetrathiafulvalene $\mathbf{1 0 b}$ in $45 \%$ and $44 \%$ yield, respectively after purification by column chromatography.

The syntheses of bis-TTFs 11-14, also based on a multi-step procedure, were carried out as shown in Scheme 3. The electrodonors 11a and 11b containing two TTF units were obtained in a mixture of cis/trans isomers in $40 \%$ and $38 \%$ yield, respectively, by using the reaction of 10 a or 10 bith 2,3-bis(2-cyanoethylthio)-6,7-di(methyl)tetrathiafulvalene 8 [30] using cesium hydroxide in DMF at room temperature. In this reaction, the risk of formation of a polymer is high, and to limit the polymerization it is necessary to work at high dilution (use a syringe pump). Thus, compounds 12a and 12b were obtained in $88 \%$ and $94 \%$ yield, respectively, by treatment of compounds 11a or 11b by cesium hydroxide in DMF at room temperature.

After, the nitro group of bis-TTFs $\mathbf{1 2 a}$ or $\mathbf{1 2} \mathbf{b}$ was reduced into an amino group in ethanol at reflux in the presence of tin and hydrochloric acid. The amino substituted bis-TTFs derivatives 13a or 13b were obtained after purification by column chromatography in $52 \%$ and $48 \%$ yield, respectively.

Finally the alkylation of amino bis-TTFs $13 \mathbf{a}$ or $13 \mathbf{b}$ was effected by treatment with $\mathrm{K}_{2} \mathrm{CO}_{3}$ (2 equiv.) and with 4 equivalents of iodomethane at room temperature, the dimethylamino bis-TTFs $\mathbf{1 4 a}$ or $\mathbf{1 4} \mathbf{b}$ were isolated by filtration and then extracted with $\mathrm{CH}_{2} \mathrm{Cl}_{2}$ and washed with water. $\mathbf{1 4 a}$ and 14b were obtained in $76 \%$ and $75 \%$ yields, respectively.

In the ${ }^{1} \mathrm{H}$ NMR spectra of compound 9, protons of $\mathrm{CH}=\mathrm{C}$ exhibit a singlet at $\delta 6.82 \mathrm{ppm}$, in addition, protons of $\mathrm{CH}_{2} \mathrm{CN}$ showed a triplet at $2.78 \mathrm{ppm}$ and $2.83 \mathrm{ppm}$, with coupling constants of $7.07 \mathrm{~Hz}$ and $6.00 \mathrm{~Hz}$, respectively. Thus, the protons $\mathrm{SCH}_{2}$ showed a triplet at $3.14 \mathrm{ppm}$ and $3.21 \mathrm{ppm}$, with coupling constants of $7.07 \mathrm{~Hz}$ and $6.00 \mathrm{~Hz}$, respectively. The ${ }^{1} \mathrm{H}$ NMR spectra of the 10a,b revealed the absence of the $\mathrm{CH}_{2} \mathrm{CH}_{2} \mathrm{CN}$ group protons and the presence of $\left(\mathrm{CH}_{2}\right)_{n} \mathrm{Br}$ protons. 10a showed two triplets at $3.30 \mathrm{ppm}$ and at $3.85 \mathrm{ppm}$ with coupling constants of $6.72 \mathrm{~Hz}$ and $6.33 \mathrm{~Hz}$, respectively. 10b showed a multiplet at $2.15 \mathrm{ppm}$ and two triplets at $2.93 \mathrm{ppm}$ and at $3.55 \mathrm{ppm}$, with coupling constants of $6.78 \mathrm{~Hz}$ and $6.36 \mathrm{~Hz}$, respectively. Further confirmation for the structure of 12a,b was obtained from their mass spectral data, where they showed ion peaks at $[\mathrm{M}+\mathrm{H}]^{+} 739$ and $[\mathrm{M}+\mathrm{H}]^{+} 767$, respectively, and by their ${ }^{1} \mathrm{H}$ RMN spectra, the aromatic protons for $\mathbf{1 2 a}$ as two doublets at $7.55 \mathrm{ppm}$ and at $8.25 \mathrm{ppm}$, with the same coupling constants of $9.37 \mathrm{~Hz}$, as well as another characteristic triplet at $3.59 \mathrm{ppm}$ for the two $\left(\mathrm{CH}_{2}\right)_{2}$ groups protons. On the other hand, the spectrum of $\mathbf{1 2 b}$ exhibited a multiplet at $2.47 \mathrm{ppm}$ for the two $\mathrm{CH}_{2} \mathrm{CH}_{2} \mathrm{CH}_{2}$ groups. Moreover, the spectra of 13a,b showed amino group protons as multiplet around 3.50-3.85 ppm. The final products 14a,b showed the absence of the amino group proton signals and the presence of dimethylamino group proton signals as singlets at 3.35 ppm and at $3.20 \mathrm{ppm}$, respectively.

\subsection{Electrochemical Studies}

The redox behavior of these new functional mono- and bis-TTF was studied in solution by cyclic voltammetry $(\mathrm{CV})$ and by square wave voltammetry (SQW). Measurements were performed under nitrogen at room temperature using a glassy carbon working electrode, a Pt counter electrode and a standard calomel electrode (SCE) as reference, with tetrabutylammonium perchlorate $\left(n-\mathrm{Bu}_{4} \mathrm{NClO}_{4}\right.$, $0.1 \mathrm{M}$ ) in dry acetonitrile, as supporting electrolyte. A scan rate of $100 \mathrm{~m} \cdot \mathrm{Vs}^{-1}$ was used. The CV 
measurements showed reversible redox waves for all the compounds studied and the corresponding oxidation potentials Eox were determined by the SQW technique. The results are summarized in Table 1.

The type I (a) SQW curve shows two sharp oxidation waves each with one electron process for the mono-TTF (Figure 1a). This kind of voltammogramm is observed for compounds $\mathbf{9 , 1 0 a}$ and $\mathbf{1 0 b}$. The type II (b) SQW curve is observed for compounds 11a,b, 12a,b, 13a,b and 14a,b (Figure 1b). We can clearly see three oxidation peaks with respectively a 1,1 and 2 electron process. The real distinction of the two first oxidation waves is clearly due to the difference of the two TTF units of the bis-TTFs.

Table 1. Oxidation potential of mono- and bis-tetrathiafulvalenes (bis-TTF)s.

\begin{tabular}{ccccc}
\hline Donor & $\boldsymbol{E}_{\mathbf{0 x}}^{\mathbf{1}(\mathbf{m V})}$ & $\boldsymbol{E}_{\mathbf{0 x}}^{\mathbf{2}}(\mathbf{m V})$ & $\boldsymbol{E}_{\mathbf{0 x}}^{\mathbf{3}}(\mathbf{m V})$ & $\boldsymbol{\Delta} \boldsymbol{E}_{\mathbf{0 x}}(\mathbf{m V})$ \\
\hline $\mathbf{9}$ & 652 & 988 & - & 336 \\
$\mathbf{1 0 a}$ & 643 & 980 & - & 337 \\
$\mathbf{1 0 b}$ & 640 & 977 & - & 337 \\
$\mathbf{1 1 a}$ & 553 & 687 & 1018 & 465 \\
$\mathbf{1 1 b}$ & 550 & 684 & 1014 & 464 \\
$\mathbf{1 2 a}$ & 538 & 673 & 1004 & 466 \\
$\mathbf{1 2 b}$ & 536 & 670 & 1001 & 465 \\
$\mathbf{1 3 a}$ & 514 & 646 & 978 & 464 \\
$\mathbf{1 3 b}$ & 512 & 643 & 974 & 462 \\
$\mathbf{1 4 a}$ & 530 & 665 & 996 & 466 \\
$\mathbf{1 4 b}$ & 528 & 663 & 994 & 466 \\
\hline
\end{tabular}

Figure 1. Voltammogram of mono-TTF 9 (type I) (a) and bis-TTF 14a (type II) (b).
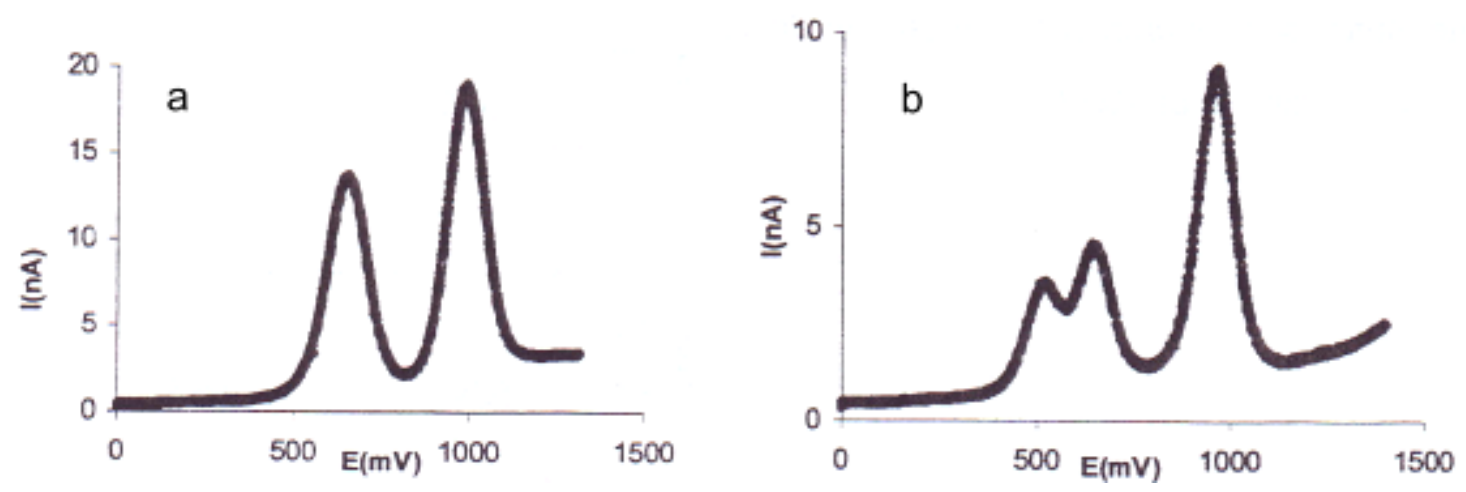

The oxidation potentials are almost identical for each pair of bis-donors (11a, 11b), (12a, 12b), (13a, 13b) and (14a, 14b). The first oxidation potentials in each pair are shifted cathodically by $20 \mathrm{mV}$. This may be due to the alkyl linked group. The oxidation potentials of compounds $\mathbf{1 4 a}, \mathbf{b}$ are slightly higher than that of compounds $\mathbf{1 3 a}, \mathbf{b}$, on the other hand, the compounds $\mathbf{1 2 a}, \mathbf{b}$ are slightly higher than that of compounds $\mathbf{1 4 a}, \mathbf{b}$. This should be attributable to the electronic properties of the nitrophenyl, aminophenyl and dimethylaminophenyl groups. All the oxidation potential values measured for mono-TTFs were found higher than the oxidation potentials of bis-TTFs. These results showed the good donor ability of this new series of mono-TTFs derivatives, which consequently should lead to conducting materials. 


\subsection{Preparation and Electrical Conductivity of Charge Transfer Complexes}

The first report on the electrical conductivity in an organic solid appeared in 1954 [31], namely, a perylene-bromine complex, which has a room-temperature conductivity of $0.1 \mathrm{~S} \mathrm{~cm}^{-1}$. In 1960 , the organic acceptor TCNQ [32] was synthesized as well as a great number of its conducting charge-transfer complexes and radical ion salts.

In the 1970s, the organic donor TTF [33] led to the first organic metal TTF-TCNQ [1]. Its room-temperature conductivity $\left(500 \mathrm{~S} \mathrm{~cm}^{-1}\right)$ increases with a decrease of the temperature to the value of $6000 \mathrm{~S} \mathrm{~cm}^{-1}$ at $60 \mathrm{~K}$ where a metal-insulator transition occurs. Since then, great interest has been devoted to this type of material, and a great number of new organic donors and acceptors have been synthesized as well as their charge-transfer salts.

Table 2. Electrical conductivity and melting points of charge transfer complexes.

\begin{tabular}{lll}
\hline Complex & $\boldsymbol{\sigma}_{\mathrm{RT}}\left(\mathbf{S ~ c m}^{-\mathbf{1}}\right)$ & $\mathbf{~ m p}\left({ }^{\circ} \mathbf{C}\right)$ \\
\hline 9-TCNQ & $1.30 \times 10^{-2}$ & 265 \\
10a-TCNQ & $3.45 \times 10^{-1}$ & 215 \\
10b-TCNQ & $8.60 \times 10^{-1}$ & 209 \\
11a-TCNQ & $4.36 \times 10^{-3}$ & 231 \\
11b-TCNQ & $6.82 \times 10^{-3}$ & 226 \\
12a-TCNQ & $0.27 \times 10^{-3}$ & 274 \\
12b-TCNQ & $2.85 \times 10^{-3}$ & 268 \\
13a-TCNQ & $4.35 \times 10^{-4}$ & 234 \\
13b-TCNQ & $7.20 \times 10^{-4}$ & 228 \\
14a-TCNQ & $0.54 \times 10^{-6}$ & 247 \\
14b-TCNQ & $1.30 \times 10^{-6}$ & 239 \\
\hline
\end{tabular}

Therefore, the complexation of the donors 9-14 with 7,7,8,8-tetracyanoquinodimethane (TCNQ) in hot acetonitrile solution gave the corresponding charge transfer complexes (CTC). Most of the solids were isolated in powder forms. Electrical conductivity was only measured on compressed pellets at room temperature using a two probe technique. The results are reported in Table 2.

For this family of materials, only CTC 9-TCNQ, 10a-TCNQ and 10b-TCNQ resulting from monoTTFs, can be classified in the area of conductors. In fact, they have a conductivity measured on powder compressed pellets of $8.6010^{-1}$ to $1.3010^{-2} \mathrm{~S} \mathrm{~cm}^{-1}$, that allows a conductivity ten times greater on single crystal.

Other, CTC resulting from bis-TTFs can be classified in the category of semi-conductors materials with conductivities from $10^{-3}$ to $10^{-6} \mathrm{~S} \mathrm{~cm}^{-1}$. This can be due to a structural disorder and/or a full charge transfer of an electron for each molecule.

\section{Experimental Section}

\subsection{General}

NMR spectra were recorded on a Brucker AC 250 instrument. Microanalyses were performed in the Microanalysis Laboratory of ENSCM (Montpellier). FAB mass spectra were recorded on a JOEL 
JMS-DX 300 spectrometer. Uncorrected melting points were measured on a 510 Buchi apparatus. Cyclic voltammetry measurements were carried out on a PAR-273 potentiostat/galvanostat. All solvents were dried by standard methods and all commercial reagents used without purification. All reactions were performed under an inert atmosphere of nitrogen.

\subsection{2-Methylthio-4-(p-nitrophenyl)-1,3-dithiolium Trifluoromethane Sulfonate 2}

A suspension of 4-( $p$-nitrophenyl)-1,3-dithiole-2-thione $1 \mathrm{a}(4.28 \mathrm{~g}, 16.81 \mathrm{mmol})$ in dry methylene chloride $(25 \mathrm{~mL})$ was treated with methyl triflate $(2.4 \mathrm{~mL}, 19.2 \mathrm{mmol})$ at $0{ }^{\circ} \mathrm{C}$. The mixture was stirred under nitrogen for $4 \mathrm{~h}$ and dry ether $(150 \mathrm{~mL})$ was added. The violet-orange salt 2 was obtained by filtration after $24 \mathrm{~h}$, washed with more dry ether, and dried. Yield $=95 \%$; orange powder, $\mathrm{mp}=237{ }^{\circ} \mathrm{C} ;{ }^{1} \mathrm{H}$ NMR $\left(\mathrm{CDCl}_{3}\right) \delta \mathrm{ppm}: 3.10\left(\mathrm{~s}, 3 \mathrm{H}, \mathrm{CH}_{3} \mathrm{~S}\right) ; 7.37$ (s, 1H, HC-S); $7.53\left(\mathrm{~m}, 2 \mathrm{H}_{\text {arom }}\right) ; 8.24$ (m, $2 \mathrm{H}_{\text {arom }}$ ); M.S: (NOBA, FAB > 0): $420[\mathrm{M}+\mathrm{H}]^{+} ; \mathrm{M}=419$; Anal. Calcd for $\mathrm{C}_{11} \mathrm{H}_{8} \mathrm{~S}_{4} \mathrm{NO}_{5} \mathrm{~F}_{3}$ : C, 31.49; H, 1.92; S, 30.57; found: C, 31.70; H, 2.14; S, 30.60 .

\subsection{2-Methylthio-4-(p-nitrophenyl)-1,3-dithiole 3}

A suspension of $2(7.73 \mathrm{~g}, 18.45 \mathrm{mmol})$ in dry ethanol $(10 \mathrm{~mL})$ was treated with $\mathrm{NaBH}_{4}(3.41 \mathrm{~g}$, $92.25 \mathrm{mmol}$ ) at $0{ }^{\circ} \mathrm{C}$ under nitrogen. After the reaction mixture was stirred for $2 \mathrm{~h}$, the solvent was evaporated under vacuum. The residue was dissolved in dichloromethane $(100 \mathrm{~mL})$, washed three times with water and dried over magnesium sulphate; the product was obtained after evaporation. Yield $=75 \%$; TLC: $\mathrm{Rf}=0.85\left(\mathrm{CH}_{2} \mathrm{Cl}_{2}\right)$; dark red oil; ${ }^{1} \mathrm{H} \mathrm{NMR}\left(\mathrm{CDCl}_{3}\right) \delta$ ppm: $2.84\left(\mathrm{~s}, 3 \mathrm{H}, \mathrm{CH}_{3} \mathrm{~S}\right)$; 5.63 (s, 1H); 7.15 (s, 1H, HC-S); 7.33 (m, 2H arom); 8.00 (m, 2H arom); M.S: (NOBA, FAB > 0): 272 $[\mathrm{M}+\mathrm{H}]^{+} ; \mathrm{M}=271$; Anal. Calcd for $\mathrm{C}_{10} \mathrm{H}_{9} \mathrm{~S}_{3} \mathrm{NO}_{2}$ : C, 44.25; H, 3.34; S, 35.44; found: C, 44.00; $\mathrm{H}, 3.07$;, 35.75 .

\subsection{4-(p-Nitrophenyl)-1,3-dithiolium Tetrafluoroborate 4}

Tetrafluoroboric acid $(0.92 \mathrm{~g}, 10.60 \mathrm{mmol})$ was added dropwise under nitrogen to a solution of 3 $(2.61 \mathrm{~g}, 9.64 \mathrm{mmol})$ in $30 \mathrm{~mL}$ of acetic anhydride at $0{ }^{\circ} \mathrm{C}$. The reaction mixture was stirred for $15 \mathrm{~min}$, then anhydrous ether was added. The 1,3-dithilium salt was precipitated, collected by filtration and washed with ether. Yield $=45 \%$; white powder, $\mathrm{mp}=253{ }^{\circ} \mathrm{C} ;{ }^{1} \mathrm{H}$ NMR $\left(\mathrm{CDCl}_{3}\right) \delta$ ppm: $7.50(\mathrm{~m}$, $2 \mathrm{H}_{\text {arom }}$ ); 7.85 (s, $\left.1 \mathrm{H}, \mathrm{HC}=\mathrm{C}-\mathrm{S}\right) ; 8.20\left(\mathrm{~m}, 2 \mathrm{H}_{\text {arom }}\right) ; 9.35$ (s, 1H); M.S: (NOBA, FAB > 0): $312[\mathrm{M}+\mathrm{H}]^{+}$; $\mathrm{M}=311$; Anal. Calcd for $\mathrm{C}_{9} \mathrm{H}_{6} \mathrm{~S}_{2} \mathrm{NO}_{2} \mathrm{BF}_{4}$ : C, 34.74; H, 1.94; S, 20.61; found: C, 34.98; H, 2.16; S, 20.96.

\subsection{2,3-Bis(2-cyanoethylthio)-6-p-nitrophenyl Tetrathiafulvalene 9}

\subsubsection{Method 1}

4-( $p$-Nitrophenyl)-1,3-dithiole-2-thione 1a [26] or 4-( $p$-nitrophenyl)-1,3-dithiole-2-one 1b [28] and 5-bis-(2-cyanoethylthio)-1,3-dithiole-2-one 6 [27] were synthesized as described in the literature. Under a nitrogen atmosphere, $25 \mathrm{~mL}$ of freshly distilled triethyl phosphite was added to the mixture of $1 \mathbf{a}(0.5 \mathrm{~g}, 1.96 \mathrm{mmol})$ or $\mathbf{1 b}(0.5 \mathrm{~g}, 2.09 \mathrm{mmol})$ and $\mathbf{6}$ (1 equiv.). The resulting mixture was heated over an oil bath up to $110{ }^{\circ} \mathrm{C}$ and stirred for a further $4 \mathrm{~h}$. The solvent was then removed under reduced 
pressure. Compound 9 was obtained by column chromatography of the residue (silica gel, eluting with dichloromethane and petroleum ether (2:1)) in 35\% and 57\% yield, respectively.

\subsubsection{Method 2}

A solution of the dithiolium salt $4(0.5 \mathrm{~g}, 1.60 \mathrm{mmol})$ and (4,5-bis((2-cyanoethyl)thio)-1,3-dithiol-2yl)triphenylphosphonium tetrafluoroborate $5(0.99 \mathrm{~g}, 1.60 \mathrm{mmol})$ in acetonitrile $(30 \mathrm{~mL})$ was treated with triethylamine $(0.27 \mathrm{~mL}, 1.92 \mathrm{mmol})$ at room temperature under nitrogen and the reaction mixture was stirred for $4 \mathrm{~h}$, the solvent was evaporated under vacuum. The residue was purified by column chromatography on silica gel with dichloromethane and petroleum ether $(2: 1)$ as the eluent to afford 9 in $30 \%$ yield.

TLC: $\mathrm{Rf}=0.53\left(\mathrm{CH}_{2} \mathrm{Cl}_{2} /\right.$ petroleum ether) $(2: 1)$; dark-violet powder, $\mathrm{mp}=175{ }^{\circ} \mathrm{C} ;{ }^{1} \mathrm{H} \mathrm{NMR}$ $\left(\mathrm{CDCl}_{3}\right) \delta$ ppm: $2.78\left(\mathrm{t}, 2 \mathrm{H}, \mathrm{CH}_{2} \mathrm{~S}, J=7.07 \mathrm{~Hz}\right) ; 2.83\left(\mathrm{t}, 2 \mathrm{H}, \mathrm{CH}_{2} \mathrm{~S}, J=6.00 \mathrm{~Hz}\right) ; 3.14\left(\mathrm{t}, 2 \mathrm{H}, \mathrm{CH}_{2} \mathrm{CN}\right.$, $J=7.07 \mathrm{~Hz}) ; 3.21$ (t, $\left.2 \mathrm{H}, \mathrm{CH}_{2} \mathrm{CN}, J=6.00 \mathrm{~Hz}\right) ; 6.82(\mathrm{~s}, 1 \mathrm{H}, \mathrm{C}=\mathrm{CH}) ; 7.40\left(\mathrm{~d}, 2 \mathrm{H}_{\text {arom }}, J=9.00 \mathrm{~Hz}\right)$; $8.28\left(\mathrm{~d}, 2 \mathrm{H}_{\text {arom }}, J=9.00 \mathrm{~Hz}\right.$ ); M.S: (NOBA, FAB $>0$ ): $496[\mathrm{M}+\mathrm{H}]^{+} ; \mathrm{M}=495$; Anal. Calcd for $\mathrm{C}_{18} \mathrm{H}_{13} \mathrm{~S}_{6} \mathrm{~N}_{3} \mathrm{O}_{2}$ : C, 43.61; H, 2.64; S, 38.81; found: C, 43.40; H, 2.40; S, 39.06.

\subsection{Synthesis of Mono-TTFs $\mathbf{1 0 a}$ and $\mathbf{1 0 b}$}

Cesium hydroxide monohydrate $(0.62 \mathrm{~g}, 3.72 \mathrm{mmol})$ in dry methanol $(10 \mathrm{~mL})$ was added to tetrathiafulvalene dicyano derivative $9(0.5 \mathrm{~g}, 1.69 \mathrm{mmol})$ dissolved in dry and degassed DMF $(30 \mathrm{~mL})$. The reaction mixture was stirred for $10 \mathrm{~min}$, the colour becoming dark violet. Then, an excess of 1,2-dibromoethane or 1,3-dibromopropane (10 equiv.) was added in one portion. The colour of the reaction mixture became clear, and the reaction mixture was stirred at room temperature for $1 \mathrm{~h}$. The solvent was removed in vacuo, the residue was dissolved in dichloromethane $(100 \mathrm{~mL})$, washed three times with water and dried over magnesium sulphate. The mixture was concentrated in vacuo and the residue was purified by chromatography on a silica gel column (eluent: dichloromethane).

2,3-Bis(2-bromoethylthio)-6-p-nitrophenyl tetrathiafulvalene 10a: Yield $=45 \%$; TLC: $\mathrm{Rf}=0.85$ $\left(\mathrm{CH}_{2} \mathrm{Cl}_{2}\right)$; dark-violet powder, $\mathrm{mp}=93{ }^{\circ} \mathrm{C} ;{ }^{1} \mathrm{H} \mathrm{NMR}\left(\mathrm{CDCl}_{3}\right) \delta \mathrm{ppm}$ : 3.30 (t, 4H, $\left.\mathrm{SCH}_{2}, J=6.72 \mathrm{~Hz}\right)$; $3.85\left(\mathrm{t}, 4 \mathrm{H}, \mathrm{CH}_{2} \mathrm{Br}, J=6.33 \mathrm{~Hz}\right) ; 6.80(\mathrm{~s}, 1 \mathrm{H}, \mathrm{C}=\mathrm{CH}) ; 7.55\left(\mathrm{~d}, 2 \mathrm{H}_{\text {arom }}, J=9.28 \mathrm{~Hz}\right) ; 8.17\left(\mathrm{~d}, 2 \mathrm{H}_{\text {arom }}\right.$, $J=9.28 \mathrm{~Hz}$ ); M.S: (NOBA, FAB > 0): $604[\mathrm{M}+\mathrm{H}]^{+} ; \mathrm{M}=603$; Anal. Calcd for $\mathrm{C}_{15} \mathrm{H}_{14} \mathrm{~S}_{6} \mathrm{NO}_{2} \mathrm{Br}$ : C, 31.84; H, 2.17; S, 31.88; found: C, 32.09; H, 2.37; S, 31.73.

2,3-Bis(3-bromopropylthio)-6-p-nitrophenyl tetrathiafulvalene 10b: Yield $=44 \%$; TLC: $\mathrm{Rf}=0.85$ $\left(\mathrm{CH}_{2} \mathrm{Cl}_{2}\right)$; dark-violet powder, $\mathrm{mp}=84{ }^{\circ} \mathrm{C} ;{ }^{1} \mathrm{H} \mathrm{NMR}\left(\mathrm{CDCl}_{3}\right) \delta \mathrm{ppm}: 2.15\left(\mathrm{~m}, 4 \mathrm{H}, \mathrm{SCH}_{2} \mathrm{CH}_{2} \mathrm{CH}_{2} \mathrm{Br}\right.$, $J=6.58 \mathrm{~Hz}$ ); 2.93 (t, 4H, $\left.\mathrm{SCH}_{2}, J=6.78 \mathrm{~Hz}\right) ; 3.55$ (t, 4H, $\left.\mathrm{CH}_{2} \mathrm{Br}, J=6.36 \mathrm{~Hz}\right) ; 6.76(\mathrm{~s}, 1 \mathrm{H}, \mathrm{C}=\mathrm{CH})$; $7.50\left(\mathrm{~d}, 2 \mathrm{H}_{\text {arom }}, J=9.38 \mathrm{~Hz}\right) ; 8.20$ (d, $2 \mathrm{H}_{\text {arom }}, J=9.38 \mathrm{~Hz}$ ); M.S: (NOBA, FAB > 0): $632[\mathrm{M}+\mathrm{H}]^{+}$; $\mathrm{M}=631$; Anal. Calcd for $\mathrm{C}_{16} \mathrm{H}_{16} \mathrm{~S}_{6} \mathrm{NO}_{2} \mathrm{Br}$ : C, 34.23; H, 2.71; S, 30.46; found: C, 34.03; H, 2.56; S, 30.76 .

\subsection{Synthesis of Bis-TTFs 11a and 11b}

Compounds 11a and 11b were synthesized by employing the same experimental process as $\mathbf{1 0}$ from 1 equiv. of $\mathbf{1 0 a}$ or $\mathbf{1 0 b}, 1$ equiv. of 2,3-bis(2-cyanoethylthio)-6,7-di(methyl)tetrathiafulvalene $\mathbf{8}$ and 1 equiv. of cesium hydroxide. 
p-Nitrophenyl bis-tetrathiafulvalene 11a: Yield $=40 \%$; TLC: $\mathrm{Rf}=0.74\left(\mathrm{CH}_{2} \mathrm{Cl}_{2}\right)$; violet powder, $\mathrm{mp}=104{ }^{\circ} \mathrm{C} ;{ }^{1} \mathrm{H}$ NMR $\left(\mathrm{CDCl}_{3}\right) \delta \mathrm{ppm}: 1.84(\mathrm{~s}, 6 \mathrm{H}, \mathrm{C}=\mathrm{CMe}) ; 2.84\left(\mathrm{t}, 2 \mathrm{H}, \mathrm{CH}_{2} \mathrm{~S}, J=7.05 \mathrm{~Hz}\right) ; 3.19$ (t, $2 \mathrm{H}, \mathrm{CH}_{2} \mathrm{CN}, J=7.05 \mathrm{~Hz}$ ); 3.37 (t, $\left.2 \mathrm{H}, \mathrm{SCH}_{2}, J=6.70 \mathrm{~Hz}\right) ; 3.89$ (t, 2H, $\left.\mathrm{CH}_{2} \mathrm{Br}, J=6.35 \mathrm{~Hz}\right) ; 3.62$ (t, $\left.4 \mathrm{H}, \mathrm{SCH}_{2}, J=7.37 \mathrm{~Hz}\right) ; 6.85(\mathrm{~s}, 1 \mathrm{H}, \mathrm{C}=\mathrm{CH}) ; 7.56\left(\mathrm{~d}, 2 \mathrm{H}_{\text {arom }}, J=9.39 \mathrm{~Hz}\right) ; 8.26\left(\mathrm{~d}, 2 \mathrm{H}_{\text {arom }}\right.$, $J=9.39 \mathrm{~Hz}$ ); M.S: (NOBA, FAB > 0): $869[\mathrm{M}+\mathrm{H}]^{+} ; \mathrm{M}=868$; Anal. Calcd for $\mathrm{C}_{27} \mathrm{H}_{19} \mathrm{~S}_{12} \mathrm{~N}_{2} \mathrm{O}_{2} \mathrm{Br}$ : C, 37.35; H, 2.21; S, 44.32; found: C, 37.60; H, 2.46; S, 44.12.

p-Nitrophenyl bis-tetrathiafulvalene 11b: Yield $=38 \%$; TLC: $\mathrm{Rf}=0.74\left(\mathrm{CH}_{2} \mathrm{Cl}_{2}\right)$; violet powder, m.p. $=96{ }^{\circ} \mathrm{C} ;{ }^{1} \mathrm{H}$ NMR $\left(\mathrm{CDCl}_{3}\right) \delta$ ppm: $1.80(\mathrm{~s}, 6 \mathrm{H}, \mathrm{C}=\mathrm{CMe}) ; 2.81\left(\mathrm{t}, 2 \mathrm{H}, \mathrm{CH}_{2} \mathrm{~S}, J=7.05 \mathrm{~Hz}\right) ; 3.16$ (t, $2 \mathrm{H}, \mathrm{CH}_{2} \mathrm{CN}, J=7.05 \mathrm{~Hz}$ ); 2.09 (m, 2H, SCH${ }_{2} \mathrm{CH}_{2} \mathrm{CH}_{2} \mathrm{Br}, J=6.56 \mathrm{~Hz}$ ); 2.88 (t, 2H, $\mathrm{SCH}_{2}, J=6.74 \mathrm{~Hz}$ ); $3.52\left(\mathrm{t}, 2 \mathrm{H}, \mathrm{CH}_{2} \mathrm{Br}, J=6.30 \mathrm{~Hz}\right) ; 2.45\left(\mathrm{~m}, 2 \mathrm{H}, \mathrm{SCH}_{2} \mathrm{CH}_{2} \mathrm{CH}_{2} \mathrm{~S}\right) ; 2.95\left(\mathrm{t}, 4 \mathrm{H}, \mathrm{SCH}_{2}\right) ; 6.82(\mathrm{~s}, 1 \mathrm{H}$,

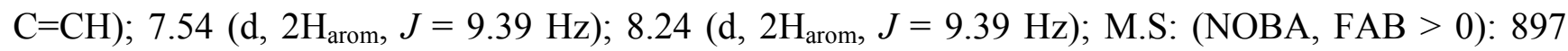
$[\mathrm{M}+\mathrm{H}]^{+} ; \mathrm{M}=896$; Anal. Calcd for $\mathrm{C}_{29} \mathrm{H}_{23} \mathrm{~S}_{12} \mathrm{~N}_{2} \mathrm{O}_{2} \mathrm{Br}$ : C, 38.87; H, 2.59; S, 42.93; found: C, 39.07; H, $2.80 ; \mathrm{S}, 42.74$.

\subsection{Synthesis of Bis-TTFs $\mathbf{1 2 a}$ and $\mathbf{1 2 b}$}

Compounds 12a and 12b were synthesized by employing the same experimental process as $\mathbf{1 0}$ from 1 equiv. of $11 \mathbf{a}$ or $\mathbf{1 1 b}$ and 1 equiv. cesium hydroxide.

p-Nitrophenyl bis-tetrathiafulvalene 12a: Yield $=88 \%$; TLC: $\mathrm{Rf}=0.70\left(\mathrm{CH}_{2} \mathrm{Cl}_{2}\right)$; violet powder, $\mathrm{mp}=163{ }^{\circ} \mathrm{C} ;{ }^{1} \mathrm{H} \mathrm{NMR}\left(\mathrm{CDCl}_{3}\right) \delta \mathrm{ppm}: 1.55(\mathrm{~s}, 6 \mathrm{H}, \mathrm{C}=\mathrm{CMe}) ; 3.59\left(\mathrm{t}, 8 \mathrm{H}, \mathrm{SCH}_{2}, J=7.40 \mathrm{~Hz}\right) ; 6.83$ (s, $1 \mathrm{H}, \mathrm{C}=\mathrm{CH}) ; 7.55\left(\mathrm{~d}, 2 \mathrm{H}_{\text {arom }}, J=9.37 \mathrm{~Hz}\right) ; 8.25\left(\mathrm{~d}, 2 \mathrm{H}_{\text {arom }}, J=9.37 \mathrm{~Hz}\right)$; M.S: (NOBA, FAB > 0): 739 $[\mathrm{M}+\mathrm{H}]^{+} ; \mathrm{M}=738$; Anal. Calcd for $\mathrm{C}_{24} \mathrm{H}_{21} \mathrm{~S}_{12} \mathrm{NO}_{2}$ : C, 39.05; H, 2.59; S, 52.12; found: C, 39.30; $\mathrm{H}$, 2.69; S, 51.92 .

p-Nitrophenyl bis-tetrathiafulvalene 12b: Yield = 94\%; TLC: $\mathrm{Rf}=0.70\left(\mathrm{CH}_{2} \mathrm{Cl}_{2}\right)$; violet powder, m.p. $=155{ }^{\circ} \mathrm{C} ;{ }^{1} \mathrm{H}$ NMR $\left(\mathrm{CDCl}_{3}\right) \delta$ ppm: 1.55 (s, 6H, C=CMe); $2.47\left(\mathrm{~m}, 4 \mathrm{H}, \mathrm{SCH}_{2} \mathrm{CH}_{2} \mathrm{CH}_{2} \mathrm{~S}\right) ; 2.99$ (t, $\left.8 \mathrm{H}, \mathrm{SCH}_{2}\right) ; 6.83(\mathrm{~s}, 1 \mathrm{H}, \mathrm{C}=\mathrm{CH}) ; 7.55\left(\mathrm{~d}, 2 \mathrm{H}_{\text {arom }}, J=9.39 \mathrm{~Hz}\right) ; 8.25\left(\mathrm{~d}, 2 \mathrm{H}_{\text {arom}}, J=9.39 \mathrm{~Hz}\right)$; M.S: (NOBA, FAB > 0): $767[\mathrm{M}+\mathrm{H}]^{+} ; \mathrm{M}=766$; Anal. Calcd for $\mathrm{C}_{25} \mathrm{H}_{23} \mathrm{~S}_{12} \mathrm{NO}_{2}: \mathrm{C}, 40.75 ; \mathrm{H}, 3.02 ; \mathrm{S}$, 50.21; found: C, 40.95; H, 3.17; S, 49.96.

\subsection{Synthesis of Bis-TTFs $\mathbf{1 3 a}$ and $\mathbf{1 3 b}$}

A stirred mixture of 4- $p$-nitrophenyl-bis-TTFs derivatives $\mathbf{1 2 a}$ or $\mathbf{1 2 b}(4 \mathrm{mmol})$, tin (0.94 g, $8 \mathrm{mmol})$, and aqueous solution of $\mathrm{HCl}(35 \%)(1.8 \mathrm{~mL}, 20 \mathrm{mmol})$ in ethanol $(30 \mathrm{~mL})$ was refluxed for $4 \mathrm{~h}$ under nitrogen. During this time the initial black solution turned light yellow. The solution was then concentrated in vacuo and treated with an aqueous solution $(100 \mathrm{~mL})$ of sodium hydroxide $(0.1 \mathrm{M})$ and extracted with ether. The organic phase was washed with water, dried $\left(\mathrm{MgSO}_{4}\right)$, and concentrated in vacuo. The product was subjected to column chromatography on silica gel $\left(\mathrm{CH}_{2} \mathrm{Cl}_{2}\right)$, affording the expected compounds 13a and $\mathbf{1 3 b}$ as powder.

p-Aminophenyl bis-tetrathiafulvalene 13a: Yield = 52\%; TLC: $\mathrm{Rf}=0.62\left(\mathrm{CH}_{2} \mathrm{Cl}_{2}\right)$; dark-orange powder, $\mathrm{mp}=138{ }^{\circ} \mathrm{C} ;{ }^{1} \mathrm{H} \mathrm{NMR}\left(\mathrm{CDCl}_{3}\right) \delta \mathrm{ppm}: 1.53(\mathrm{~s}, 6 \mathrm{H}, \mathrm{C}=\mathrm{CMe}) ; 3.50\left(\mathrm{t}, 8 \mathrm{H}, \mathrm{SCH}_{2}, J=7.38 \mathrm{~Hz}\right)$; 3.55-3.85 (m, 2H, NH $)$; $6.72(\mathrm{~s}, 1 \mathrm{H}, \mathrm{C}=\mathrm{CH}) ; 6.60$ (d, 2 $\left.\mathrm{H}_{\text {arom }}, J=8.47 \mathrm{~Hz}\right) ; 7.09$ (d, 2 $\left.\mathrm{H}_{\text {arom }}, J=8.37 \mathrm{~Hz}\right)$; M.S: (NOBA, FAB > 0): $709[\mathrm{M}+\mathrm{H}]^{+} ; \mathrm{M}=708$; Anal. Calcd for $\mathrm{C}_{24} \mathrm{H}_{23} \mathrm{~S}_{12} \mathrm{~N}$ : C, 40.70; H, 2.98; S, 54.33; found: C, 40.97; H, 3.09; S, 54.04. 
p-Aminophenyl bis-tetrathiafulvalene 13b: Yield $=48 \%$; TLC: $\mathrm{Rf}=0.62\left(\mathrm{CH}_{2} \mathrm{Cl}_{2}\right)$; dark-orange powder, m.p. $=132{ }^{\circ} \mathrm{C} ;{ }^{1} \mathrm{H}$ NMR $\left(\mathrm{CDCl}_{3}\right) \delta$ ppm: $1.54(\mathrm{~s}, 6 \mathrm{H}, \mathrm{C}=\mathrm{CMe}) ; 2.44\left(\mathrm{~m}, 4 \mathrm{H}, \mathrm{SCH}_{2} \mathrm{CH}_{2} \mathrm{CH}_{2} \mathrm{~S}\right)$; $2.95\left(\mathrm{t}, 8 \mathrm{H}, \mathrm{SCH}_{2}\right) ; 3.50-3.80\left(\mathrm{~m}, 2 \mathrm{H}, \mathrm{NH}_{2}\right) ; 6.70(\mathrm{~s}, 1 \mathrm{H}, \mathrm{C}=\mathrm{CH}) ; 6.60\left(\mathrm{~d}, 2 \mathrm{H}_{\text {arom }}, J=8.37 \mathrm{~Hz}\right) ; 7.09$ $\left(\mathrm{d}, 2 \mathrm{H}_{\text {arom }}, J=8.49 \mathrm{~Hz}\right.$ ); M.S: (NOBA, FAB > 0): $737[\mathrm{M}+\mathrm{H}]^{+} ; \mathrm{M}=736$; Anal. Calcd for $\mathrm{C}_{25} \mathrm{H}_{25} \mathrm{~S}_{12} \mathrm{~N}$ : C, 42.41; H, 3.42; S, 52.26; found: C, 42.70; H, 3.54; S, 52.10.

\subsection{Synthesis of Bis-TTFs 14a and 14b}

To a stirred solution of 4-aminophenyl-bis-TTF 13a or $13 \mathbf{b}(3 \mathrm{mmol})$ and of iodomethane $(0.75 \mathrm{~mL}$, $12 \mathrm{mmol})$ in acetone $(15 \mathrm{~mL})$ under nitrogen, $\mathrm{K}_{2} \mathrm{CO}_{3}(0.83 \mathrm{~g}, 6 \mathrm{mmol})$ was added. After 4 days of stirring at room temperature, the precipitate obtained was filtered, washed with acetone, and then extracted with $\mathrm{CH}_{2} \mathrm{Cl}_{2}$. The organic phase was dried $\left(\mathrm{MgSO}_{4}\right)$ and concentrated in vacuo, providing the expected compounds $14 \mathrm{a}$ and $14 \mathrm{~b}$ as dark orange powder.

p-Dimethylaminophenyl bis-tetrathiafulvalene 14a: Yield $=76 \%$; TC: $\mathrm{Rf}=0.78\left(\mathrm{CH}_{2} \mathrm{Cl}_{2}\right)$; orange powder, mp $=182{ }^{\circ} \mathrm{C} ;{ }^{1} \mathrm{H}$ NMR $\left(\mathrm{CDCl}_{3}\right) \delta$ ppm: $1.53(\mathrm{~s}, 6 \mathrm{H}, \mathrm{C}=\mathrm{CMe}) ; 3.35\left(\mathrm{~s}, 6 \mathrm{H}, \mathrm{NMe}_{2}\right) ; 3.51$ $\left(\mathrm{t}, 8 \mathrm{H}, \mathrm{SCH}_{2}, J=7.37 \mathrm{~Hz}\right) ; 6.61(\mathrm{~s}, 1 \mathrm{H}, \mathrm{C}=\mathrm{CH}) ; 7.71\left(\mathrm{~d}, 2 \mathrm{H}_{\text {arom }}, J=8.85 \mathrm{~Hz}\right) ; 8.00\left(\mathrm{~d}, 2 \mathrm{H}_{\text {arom }}\right.$, $J=8.90 \mathrm{~Hz}$ ); M.S: (NOBA, FAB > 0): $737[\mathrm{M}+\mathrm{H}]^{+} ; \mathrm{M}=736$; Anal. Calcd for $\mathrm{C}_{26} \mathrm{H}_{27} \mathrm{~S}_{12} \mathrm{~N}: \mathrm{C}, 42.41$; H, 3.42; S, 52.26; found: C, 42.13; H, 3.28; S, 52.57.

p-Dimethylaminophenyl bis-tetrathiafulvalene 14b: Yield $=75 \%$; TLC: $\mathrm{Rf}=0.78\left(\mathrm{CH}_{2} \mathrm{Cl}_{2}\right)$; orange powder, mp $=176{ }^{\circ} \mathrm{C} ;{ }^{1} \mathrm{H} \mathrm{NMR}\left(\mathrm{CDCl}_{3}\right) \delta \mathrm{ppm}$ : $1.54(\mathrm{~s}, 6 \mathrm{H}, \mathrm{C}=\mathrm{CMe}) ; 2.43\left(\mathrm{~m}, 4 \mathrm{H}, \mathrm{SCH}_{2} \mathrm{CH}_{2} \mathrm{CH}_{2} \mathrm{~S}\right)$; $2.96\left(\mathrm{t}, \quad 8 \mathrm{H}, \quad \mathrm{SCH}_{2}\right) ; \quad 3.35 \quad\left(\mathrm{~s}, \quad 6 \mathrm{H}, \quad \mathrm{NMe}_{2}\right) ; 6.60 \quad(\mathrm{~s}, \quad 1 \mathrm{H}, \mathrm{C}=\mathrm{CH}) ; 7.71 \quad\left(\mathrm{~d}, \quad 2 \mathrm{H}_{\text {arom }}\right.$, $J=8.85 \mathrm{~Hz}) ; 8.00\left(\mathrm{~d}, 2 \mathrm{H}_{\text {arom }}, J=8.90 \mathrm{~Hz}\right)$; M.S: (NOBA, FAB $>0$ ): $765[\mathrm{M}+\mathrm{H}]^{+} ; \mathrm{M}=764$; Anal. Calcd for $\mathrm{C}_{27} \mathrm{H}_{29} \mathrm{~S}_{12} \mathrm{~N}$ : C, 44.00; H, 3.82; S, 50.34; found: C, 43.76; H, 3.63; S, 50.71 .

\section{Conclusions}

In summary, we have successfully prepared via Wittig-type, cross-coupling, reduction and alkylation synthetic strategies some new mono-TTFs and bis-TTFs containing nitrophenyl, aminophenyl or dimethylaminophenyl groups. All donors synthesized during the course of this work have been characterized by cyclic voltammetry and their oxidation potentials were determined by cyclic voltammetry. Charge transfer complexes of the donors with TCNQ were prepared and the electrical conductivity of these materials was measured, some CTC are conductive.

\section{Acknowledgments}

This work was partially supported by Algerian Research Ministry, MERS.

\section{References}

1. Ferraris, J.; Cowan, D.O.; Walatka, V.; Perlstein, J.H. Electron transfer in a new highly conducting donor-acceptor complex. J. Am. Chem. Soc. 1973, 95, 948-949.

2. Segura, J.L.; Martin, N. New concepts in tetrathiafulvalene chemistry. Angew. Chem. Int. Ed. 2001, 40, 1372-1409. 
3. Fabre, J.M. Dimensionality and electrical properties in organic synthetic metals - Current results through selected recent examples. J. Solid State Chem. 2002, 168, 367-383.

4. Clemente-León, M.; Coronado, E.; Galan-Mascaros, J.R.; Gime-nez-Saiz, C.; Gomez-Garcia, C.J.; Fabre, J.M.; Mousdis, G.A.; Papavassiliou, G.C. Hybrid molecular materials based upon organic $\pi$-electron donors and inorganic metal complexes. conducting salts of bis(ethylenediseleno)tetrathiafulvalene (BEST) with the octahedral anions hexacyanoferrate(III) and nitroprusside. J. Solid State Chem. 2002, 168, 616-625.

5. Devic, T.; Evain, M.; Moelo, Y.; Canadell, E.; Auban-Senzier, P.; Fourmigué, M.; Batail, P. Single crystalline commensurate metallic assemblages of $\pi$-slabs and $\mathrm{CdI}_{2}$-type layers: Synthesis and properties of $\beta$-(EDT-TTF- $\left.\mathrm{I}_{2}\right)_{2}\left[\mathrm{~Pb}_{5 / 61 / 6} \mathrm{I}_{2}\right]_{3}$ and $\beta-\left(\text { EDT-TTF- }{ }_{2}\right)_{2}\left[\mathrm{~Pb}_{2 / 3+x} \mathrm{Ag}_{1 / 3-2 x x} \mathrm{I}_{2}\right] 3, x=0.05$. J. Am. Chem. Soc. 2003, 125, 3295-3301.

6. Suzuki, W.; Fujiwara, E.; Kobayashi, A.; Fujishiro, Y.; Nishibori, E.; Takata, M.; Sakata, M.; Fujiwara, H.; Kobayashi, H. Highly conducting crystals based on single-component gold complexes with extended-TTF dithiolate ligands. J. Am. Chem. Soc. 2003, 125, 1486-1487.

7. Nishikawa, H.; Machida, A.; Morimoto, T.; Kikuchi, K.; Kodama, T.; Ikemoto, I.; Yamada, J.-I.; Yoshino, H.; Murata, K. A new organic superconductor, (DODHT) ${ }_{2} \mathrm{BF}_{4} \cdot \mathrm{H}_{2} \mathrm{O}$. Chem. Commun. 2003, 494-495.

8. Yamada, J.I.; Toita, T.; Akutsu, H.; Nakatsuji, S.; Nishikawa, H.; Ikemoto, I.; Kikuchi, K.; Choi, E.S.; Graf, D.; Brooks, J.S. A new organic superconductor, $\beta$-(BDA-TTP) ${ }_{2} \mathrm{GaCl}_{4}[\mathrm{BDA}-\mathrm{TTP}$ = 2,5-(1,3-dithian-2-ylidene)-1,3,4,6-tetrathiapentalene]. Chem. Commun. 2003, 2230-2231.

9. Coronado, E.; Galan-Mascaros, J.R.; Gimenez-Saiz, C.; Gomez-Garcia, C.J.; Ruis-Perez, C. Hybrid organic/inorganic molecular materials formed by tetrathiafulvalene radicals and magnetic trimeric clusters of dimetallic oxalate-bridged complexes: The series $(\mathrm{TTF})_{4}\left\{\mathrm{M}^{\mathrm{II}}\left(\mathrm{H}_{2} \mathrm{O}\right)_{2}\left[\mathrm{M}^{\mathrm{III}}(\mathrm{ox})_{3}\right]_{2}\right\} \cdot n \mathrm{H}_{2} \mathrm{O}\left(\mathrm{M}^{\mathrm{II}}=\mathrm{Mn}, \mathrm{Fe}, \mathrm{Co}, \mathrm{Ni}, \mathrm{Cu}\right.$ and $\mathrm{Zn} ; \mathrm{M}^{\mathrm{III}}=\mathrm{Cr}$ and $\mathrm{Fe}$; ox $=\mathrm{C}_{2} \mathrm{O}_{4}{ }^{2-}$ ). Eur. J. Inorg. Chem. 2003, 2003, 2290-2298.

10. Miyazaki, A.; Okabe, K.; Enomoto, K.; Nishijo, J.; Enoki, T.; Setifi, F.; Golhen, S.; Ouahab, L.; Toita, T.; Yamada, J.I. $\pi$-d Interaction-based molecular magnets. Polyhedron 2003, 22, 2227-2234.

11. Enoki, T.; Yamazaki, H.; Okabe, K.; Enomoto, K.; Kato, T.; Miyazaki, A.; Ogura, E.; Kuwqatani, Y.; Iyoda, M. Unconventional TTF-based molecular magnets. Synth. Met. 2003, 133-134, 501-503.

12. Otero, M.; Herranz, M.A.; Seoane, C.; Martin, N.; Garin, J.; Orduna, J.; Alcala, R.; Villacampa, B. Synthesis and properties of push-pull chromophores for second-order nonlinear optics derived from $\pi$-extended tetrathiafulvalenes (TTFs). Tetrahedron 2002, 58, 7463-7475.

13. Farren, C.; Christensen, C.A.; Fitzgerald, S.; Bryce, M.R.; Beeby, A. Synthesis of novel phthalocyanine-tetrathiafulvalene hybrids; intramolecular fluorescence quenching related to molecular geometry. J. Org. Chem. 2002, 67, 9130-9139.

14. Bryce, M.R. Functionalised tetrathiafulvalenes: New applications as versatile $\pi$-electron systems in materials chemistry. J. Mater. Chem. 2000, 10, 589-598.

15. Asakawa, M.; Ashton, P.R.; Balzani, V.; Credi, A.; Hamers, C.; Mattersteig, G.; Montalti, M.; Shipway, A.N.; Spencer, N.; Stoddart, J.F.; et al. A chemically and electrochemically switchable [2] catenane incorporating a tetrathiafulvalene unit. Angew. Chem. Int. Engl. 1998, 37, 333-337. 
16. Laukhina, E.; Vidal-Gancedo, J.; Laukhin, V.; Veciana, J.; Chuev, I.; Tkacheva, V.; Wurst, K.; Rovira, C. Multistability in a BEDT-TTF based molecular conductor. J. Am. Chem. Soc. 2003, 125, 3948-3953.

17. Nishikawa, H.; Machida, A.; Morimoto, T.; Kikuchi, K.; Kodama, T.; Ikemoto, I.; Yamada, J.I.; Yoshino, H.; Murata, K. A new organic superconductor, (DODHT) $)_{2} \mathrm{BF}_{4} \cdot \mathrm{H}_{2} \mathrm{O}$. Chem. Commun. 2003, 494-495.

18. Martin, N.; Sanchez, L.; Guldi, D.M. Stabilisation of charge-separated states via gain of aromaticity and planarity of the donor moiety in $\mathrm{C}_{60}$-based dyads. Chem. Commun. 2000, 113-114.

19. Roncali, J. Linearly extended $\pi$-donors: When tetrathiafulvalene meets conjugated oligomers and polymers. J. Mater. Chem. 1997, 7, 2307-2321.

20. Hansen, T.K.; Jorgensen, T.; Stein, P.C.; Becher, J. Crown ether derivatives of tetrathiafulvalene. J. Org. Chem. 1992, 57, 6403-6409.

21. Bengs, H.; Ebert, M.; Karthaus, O.; Kohne, B.; Praefcke, K.; Ringsdorf, H.; Wendorff, J.H.; Wustefeld, R. Induction and variation of discotic columnar phases through doping with electron acceptors. Adv. Mater. 1990, 2, 141-144.

22. Bryce, M.R.; Devonport, W.; Goldenberg, L.M.; Wang, C. Macromolecular tetrathiafulvalene chemistry. Chem. Commun. 1998, 9, 945-952.

23. Abbaz, T.; Gouasmia, A.K.; Fujiwara, H.; Hiraoka, T.; Sugimoto, T.; Taillefer, M.; Fabre, J.M. New TTF and bis-TTF containing thiophene units: Electrical properties of the resulting salts. Synth. Met. 2007, 157, 508-516.

24. Subias, G.; Abbaz, T.; Fabre, J.M.; Fraxedas, J. Characterization of the anion-ordering transition in (TMTTF $)_{2} \mathrm{ReO}_{4}$ by x-ray absorption and photoemission spectroscopies. Phys. Rev. B 2007, 76, 085103-085107.

25. Lamère, J.F.; Malfant, I.; Sournia-Saquet, A.; Lacroix, P.G.; Fabre, J.M.; Kaboub, L.; Abbaz, T.; Gouasmia, A.K.; Asselberghs, I.; Clays, K. Quadratic nonlinear optical response in partially charged donor-substituted tetrathiafulvalene: From a computational investigation to a rational synthetic feasibility. Chem. Mater. 2007, 19, 805-815.

26. Clausen, R.P.; Becher, J. The 1,2,3-thiadiazole route to new vinylogue tetrathiafulvalenes. Tetrahedron 1996, 52, 3171-3188.

27. Binet, L.; Fabre, J.M.; Montginoul, C.; Simonsen, K.B.; Becker. J. Reparation and chemistry of new unsymmetrically substituted tetrachalcogenofulvalenes bearing $\mathrm{CN}\left(\mathrm{CH}_{2}\right)_{2} \mathrm{X}$ and $\mathrm{HO}\left(\mathrm{CH}_{2}\right)_{2} \mathrm{X}$ groups (X=S or Se). J. Chem. Soc. Perkin Trans. 1996, 1, 783-788.

28. Campaigne, E.; Hamilton, R.D.; Jacobsen, N.W. Dithiolium derivatives. II. Some new 1,3-dithiolium perchlorates. J. Org. Chem. 1964, 29, 1708-1710.

29. Misaki, Y.; Nishikawa, H.; Kawakami, K.; Yamabe, T.; Mori, T.; Inokuchi, H.; Mori, H.; Tanaka, S. Ethylenedioxy substituted 2,5-bis(1',3'-dithiol-2'-ylidene)-1,3,4,6-tetrathiapentalenes and their conducting salts. Chem. Lett. 1993, 22, 2073-2076.

30. Binet, L.; Fabre, J.M. Synthesis of new functionalized $\pi$-electron donors: Primary hydroxy and primary amino multisulfur tetrathiafulvalenes. Synthesis 1997, 10, 1179-1184.

31. Akamatu, H.; Inokuchi, H.; Matsunaga, Y. Organic semiconductors with high conductivity. I. Complexes between polycyclic aromatic hydrocarbons and halogens. Bull. Chem. Soc. Jpn. 1956, $29,213-218$. 
32. Acker, D.S.; Harder, R.J.; Hertler, W.R.; Mahler, W.; Melby, L.R.; Benson, R.E.; Mochel, W.E. 7,7,8,8-tetracyanoqunodimethane and its electrically conducting anion-radical derivatives. $J$. Am. Chem. Soc. 1960, 82, 6408-6409.

33. Wudl, F.; Smith, G.M.; Hufnagel, E. 1,3-Bis-dithiole chloride. J. Chem. Soc. D Chem. Commun. 1970, 1453-1954.

(C) 2012 by the authors; licensee MDPI, Basel, Switzerland. This article is an open access article distributed under the terms and conditions of the Creative Commons Attribution license (http://creativecommons.org/licenses/by/3.0/). 